\title{
Flower opening and vase life of gladiolus cultivars: the sensitivity to ethylene and the carbohydrate content ${ }^{(1)}$
}

\author{
LUCAS CAVALCANTE DA COSTA ${ }^{(2) *}$ and FERNANDO LUIZ FINGER ${ }^{(2)}$
}

\begin{abstract}
Vase life is one of the most important characteristics in the quality of cut flowers. The carbohydrate content of petals from each cultivar can be a decisive factor to vase life of gladiolus flowers. Despite exposure to ethylene does not affect the life of open florets of gladiolus flowers, it may reduce the flower's commercial life due the occurrence of flower buds abortion. This study thus aimed to evaluate the flower opening and the vase life of gladiolus flowers according to ethylene sensitivity and carbohydrate content of each cultivar. The gladiolus cultivars used in Experiment I were 'Amsterdam', 'Blue Frost', 'Gold Field', 'Green Star', 'Jester', 'Lavender', 'Red Beauty', 'Rose Supreme', 'Traderhorn', and 'Verônica'. Stems were stored in airtight chambers and exposed to the ethylene concentrations of $0,0.1,1.0,10,100$, and $1000 \mu \mathrm{L} \mathrm{L}^{-1}$ for $24 \mathrm{~h}$. Subsequently, flower stem were placed in a test tube with distilled water when were evaluated for percentage of flower opening and vase life. In Experiment II, three cultivars ('Amsterdam', 'Red Beauty', and 'Verônica') were chosen based on the lowest, medium, and highest vase life in Experiment I, respectively. Total soluble sugars, reducing sugars, and starch contents were evaluated in five flower developmental stages. No effect of ethylene on the flower opening or alterations in flower opening between cultivars. The vase life of gladiolus flowers differed between cultivars regardless of ethylene action. 'Veronica' and 'Amsterdam', which had the highest and lowest vase life, respectively, differed as to the total soluble sugar content. Ethylene does not influence the flower opening or vase life of the gladiolus cultivars studied. In these cultivars, the maintenance of flower opening is attributed to total soluble sugars content, which, in turn, is a major determinant of the vase life.
\end{abstract}

Keywords: Gladiolus grandiflora Hort., total soluble sugars, reducing sugars, starch.

\section{RESUMO}

Abertura floral e vida de vaso de cultivares de gladíolo: a sensibilidade ao etileno e o conteúdo de carboidratos A vida de vaso é um dos fatores mais importantes na qualidade de flores de corte. O conteúdo de carboidratos presente nas pétalas de cada variedade pode ser determinante para vida de vaso de flores de gladíolo. Apesar da exposição ao etileno não afetar a vida de vaso de hastes de gladíolo, o mesmo poderá reduzir a vida comercial da inflorescência mediante a ocorrência de aborto de botões florais. Portanto, este estudo teve como objetivo avaliar a abertura floral e a vida de vaso de flores de gladíolo em relação à sensibilidade ao etileno e ao teor de carboidratos de cada cultivar. No Experimento I, as cultivares de gladíolo utilizadas foram: 'Amsterdam', 'Blue Frost', 'Gold Field', 'Green Star', 'Jester', 'Lavender', 'Red Beauty', 'Rose Supreme', 'Traderhorn' e 'Verônica'. As hastes foram acondicionadas em câmaras hermeticamente fechadas e expostas as concentrações de $0 ; 0,1 ; 1,0 ; 10$, 100 e $1000 \mu 1 \mathrm{~L}^{-1}$ de etileno pelo período de 24 horas. Posteriormente, foram colocadas em tubos de ensaio contendo água destilada e avaliadas quanto ao percentual de abertura floral e vida de vaso. No Experimento II, três cultivares foram escolhidas ('Amsterdam', 'Red Beauty' e 'Verônica'), as quais apresentaram, respectivamente, a menor, a média e a maior vida de vaso no Experimento I. Foram avaliados os teores de açúcares solúveis totais, açúcares redutores e amido em cinco estádios de desenvolvimento da flor. Não houve efeito do etileno na abertura da flor e nenhuma alteração na abertura floral entre as cultivares. A vida de vaso das flores diferiu entre as cultivares independentemente da ação do etileno. 'Verônica' e 'Amsterdam', de maior e menor vida de vaso, respectivamente, diferiram quanto aos teores de açúcares solúveis totais. O etileno não influencia na abertura floral ou na vida de vaso das cultivares de gladíolo estudadas. Nessas cultivares, a manutenção da abertura da flor é atribuída ao conteúdo de açúcares solúveis totais, o que, por sua vez, é um parâmetro determinante da vida de vaso.

Palavras-chave: Gladiolus grandiflora Hort., açúcares solúveis totais, açúcares redutores, amido.

\footnotetext{
(1) Received in 26/04/2016 and accepted in 04/08/2016

(2) Universidade Federal de Viçosa (UFV), Departamento de Fitotecnia, Viçosa-MG, Brazil. *Corresponding author: costalc@ymail.com
} 


\section{INTRODUCTION}

Gladiolus sp., a species originating from South Africa, is a cut flower with good adaptability for development in different climatic regions. A member of the Iridaceae family, Gladiolus grandiflora (Hort.) is popularly known as gladiolus or sword lily. It's of easy cultivation, characterized by its resistance to pests and diseases, and has a large variety of flower colors (HASSAN et al., 2014; KUMAR et al, 2014), making it one of the most widely grown species of cut flowers in the world.

Cut flowers for sale need to withstand the harvest, packing, and distribution procedures and also have an acceptable quality to the final consumer. Two important characteristics of cut flowers are high flower opening capacity after stems are harvested and long vase life after opening (NABIGOL et al., 2014).

Vase life is one of the most important factors in the quality of cut flowers, and it may vary among gladiolus cultivars. There are reports that gladiolus is insensitive to ethylene (YAMADA et al., 2003; ARORA et al., 2006; KUMAR et al., 2014). In the physiological level, ethylene does not accelerate flower senescence, and its biosynthesis or action inhibitors do not delay this event. However, ethylene sensitivity varies considerably among species and even among cultivars of the same species (SEREK et al., 2006; SCARIOT et al., 2014).

The response to ethylene also varies largely according to species, although it is more commonly observed between families or subfamilies (VAN DOORN, 2001; CORDEIRO et al., 2011). According to Serek et al. (1994), despite exposure to ethylene does not affect the life of open florets of gladiolus flowers, it may reduce the flower's commercial life due the occurrence of abortion of closed buds.

Gladiolus is harvested still in the bud phase. At flower opening, a large amount of reducing sugars is necessary as substrate for respiration. Besides, flower opening is the result of from petal growth, associated with cell expansion, which requires water uptake and osmotic agents such as soluble carbohydrates (WAITHAKA et al., 2001; YAMADA et al., 2003; ELHINDI et al., 2012).

A lack of carbohydrates is correlated with shorter vase life of cut flowers (YAMANE et al., 2005; DAR et al., 2014). Therefore, the soluble carbohydrate content of cut flowers may be related to the difference in vase life between cultivars (NABIGOL et al., 2010; NABIGOL et al., 2014).

Research results suggest that the longer vase life of some cultivars may be attributed to higher concentrations of soluble carbohydrates in the petals (NABIGOL et al., 2010; NABIGOL et al., 2014). Van der Meulen-Muisers et al. (2001) used three cultivars of lily with different longevities and determined that the senescence time of cut flowers coincided with the time at which the carbohydrate content was reduced by half. This indicated a correlation between the start of senescence and lack of carbohydrates in lily petals (VAN DOORN and HAN, 2011).

It has been demonstrated that starch is a reserve of carbohydrates in cut flowers (YAP et al., 2008; NABIGOL et al., 2014). Yamane et al. (1991) observed that the predominant sugars in gladiolus flowers are fructose and glucose; however, starch was the main source of soluble carbohydrates that contributed in the initial expansion stages.

In a study conducted by Waithaka et al. (2001), the starch content decreased during floret opening; however, its contribution was lower in total carbohydrate content as a source of energy to the open florets. Thus, the authors concluded that starch was the main source of the sugars necessary for the expansion of gladiolus flowers at the beginning of development, but not for longevity.

This study thus aimed to evaluate the flower opening and vase life of gladiolus flowers according to ethylene sensitivity and carbohydrate content of each cultivar.

\section{MATERIAL AND METHODS}

\section{Location and raw material}

The experiment was conducted at Universidade Federal de Viçosa, in MG, Brazil, with 10 cultivars of Gladiolus grandiflora (Hort.). In Experiment I, the cultivars used were 'Amsterdam', 'Blue Frost', 'Gold Field', 'Green Star', 'Jester', 'Lavender', 'Red Beauty', 'Rose Supreme', 'Traderhorn', and 'Verônica'.

For Experiment II, three cultivars were chosen ('Amsterdam', 'Red Beauty', and 'Verônica') based on the lowest, medium, and highest vase life in Experiment I, respectively.

Stems were collected at the commercial harvest stage determined for the species; i.e., when the flower buds showed the specific color of the cultivar.

\section{Experimental handling}

After harvest, stems were placed in containers with water and then transferred to the laboratory, where the base of the stems was cut in water and their length standardized to $60 \mathrm{~cm}$, according to Brazilian standards (VEILING, 2009). Later, the flower stems were distributed randomly across the treatments.

\section{Experiment I}

The experimental design was completely randomized, with a $6 \times 10$ factorial arrangement (six concentrations of ethylene and ten cultivars) and five replications, each composed of three flower stems. After standardization, stems were stored in airtight chambers and exposed to ethylene concentrations of $0,0.1,1.0,10,100$, and 1000 $\mu \mathrm{L} \mathrm{L}^{-1}$ for $24 \mathrm{~h}$. After being removed from the chamber, they were placed in test tubes containing distilled water and evaluated for flower opening and vase life. The water in the tubes was renewed every $24 \mathrm{~h}$.

\section{Experiment II}

Stems of 'Amsterdam', 'Red Beauty', and 'Verônica' were placed in test tubes containing $100 \mathrm{~mL}$ distilled water and supported by a grid system to avoid tipping. During the vase life, samples used for quantification of sugars were removed from the second basal flower in all five flower opening developmental stages: (I) totally closed; (II) 
partially open; (III) totally open; (IV) partially senescent (indicating wilt of the petal borders); and (V) senescent (SEREK et al., 1994). In this experiment, we evaluated total soluble sugars, reducing sugars, and starch contents. A completely randomized design with three replications was adopted and each replication composed of five flower stems.

\section{Postharvest assessment}

Flower opening

Before exposure to exogenous ethylene in an airtight chamber, the number of buds on each inflorescence was counted. Considering that all flowers were open, the number of open flowers would be $100 \%$. Therefore, the percentage of open flowers of the other periods was estimated by the following equation:

$$
\mathrm{POF}=(\mathrm{OF} \times 100) / \mathrm{TF}
$$

POF: percentage of open flowers;

OF: number of open flowers at the stem;

TF: total number of flowers at the stem.

Vase life

Stem vase life was determined as the period (number of days) comprised between the exposure to ethylene for $24 \mathrm{~h}$ and appearance of wilt in at least $50 \%$ of the open flowers.

Sugar and starch determination

Extraction of total soluble and reducing sugars and starch

At the extraction, approximately $200 \mathrm{mg}$ of petals from the second basal flower of the stem in the five flower development stages were weighed, and $80 \%$ ethanol at boiling temperature was poured onto them. Samples were macerated in $80 \%$ ethanol and centrifuged, followed by filtration in a $50-\mathrm{mL}$ volumetric flask. This process was performed three times, and the final volume of flasks was completed to $25 \mathrm{~mL}$. The precipitate resulting from centrifugations was dried in an oven at $65^{\circ} \mathrm{C}$ for $24 \mathrm{~h}$ and stored in a desiccator for later determination of starch. The alcoholic extract was stored, under refrigeration, in sealed tubes, for quantifying the total soluble and reducing sugars.

\section{Quantification of total soluble sugars}

Total soluble sugars were quantified based on the phenol-sulfuric acid method (DUBOIS et al., 1956), by adding $250 \mu \mathrm{L}$ of the alcoholic extract and $250 \mu \mathrm{L}$ $5 \%$ phenol to a test tube, followed by vortexing. The tubes received $1.25 \mathrm{~mL}$ of concentrated sulfuric acid and were shaken again. After a water bath at $30^{\circ} \mathrm{C}$ for $20 \mathrm{~min}$, tubes were shaken once again, left at room temperature for $30 \mathrm{~min}$, and then the material was read in a spectrophotometer at a wavelength of $\lambda=490 \mathrm{~nm}$. After the absorbance was read, calculations were made with thedilution corrections. The result was compared with the $1 \%$ sucrose standard curve and expressed in $\mathrm{mg}$ $\mathrm{g}^{-1}$ fresh weight (FW).
Quantification of reducing sugars

Reducing sugars were quantified according to the methodology of Somogy-Nelson (NELSON, 1944; SOMOGY, 1945), by adding $200 \mu \mathrm{L}$ of the alcoholic extract and $200 \mu \mathrm{L}$ Nelson reagent 4 to an Eppendorf tube. Next, tubes were shaken, boiled for $15 \mathrm{~min}$, and then cooled in an ice bath. Subsequently, $200 \mu \mathrm{L}$ of Nelson reagent 5 and $600 \mu \mathrm{L}$ deionized water were added and tubes were shaken again. The material was red in a spectrophotometer at a $540 \mathrm{~nm}$ wavelength. The result was compared with the $1 \%$ glucose standard curve and expressed in $\mathrm{mg} \mathrm{g}^{-1} \mathrm{FW}$.

\section{Quantification of starch}

The method described by McCready et al. (1950) was adopted for the starch quantification. Based on the residue obtained from total sugars extraction, $2.5 \mathrm{~mL}$ deionized water and $3.5 \mathrm{~mL} 52 \%$ perchloric acid were added to the dry material in centrifuge tubes. After shaking, tubes remained at rest for $30 \mathrm{~min}$. Next, a centrifugation was performed at $2000 \mathrm{rpm}$ for $15 \mathrm{~min}$, and the supernatant was collected in $25 \mathrm{~mL}$ beakers. After this procedure was repeated three times, the volume of the beakers was completed to $25 \mathrm{~mL}$ with deionized water. Starch was quantified in the same manner as total soluble sugars, following Dubois et al. (1956), with results expressed in $\mathrm{mg} \mathrm{g}^{-1} \mathrm{FW}$.

\section{Statistical analysis}

In Experiment I, the data were subjected to analysis of variance (ANOVA), at 5\% significance level for two factors (cultivar and treatment) for the flower opening and vase life parameters. Tukey's test was used at 5\% probability level in the breakdown of flower opening. In Experiment II, data was presented based on means \pm standard error.

\section{RESULTS AND DISCUSSION}

\section{Experiment I}

There was a statistically significant interaction effect between cultivars and ethylene concentrations on flower opening, and an isolated effect of the cultivar factor on stem vase life.

\section{Flower opening}

As a consequence of the breakdown performed in the analysis of the significantly interaction found, the means did not differ statistically and ranged from 57.02 to 67.16. This indicates that there was no effect of ethylene on flower opening of gladiolus flowers, and no alterations were observed in flower opening between cultivars.

Hassan et al. (2014) found that the number of open florets increased when ethylene action inhibitors, such as silver thiosulphate (STS) or 1-methylcyclopropene (1MCP), were used. Moreover, they observed that the effect was more pronounced at the highest concentrations of both treatments. In the present study, floret opening was not influenced by the ethylene concentrations. According to Kumar et al. (2014), floret opening may also be related to the levels of abscisic acid and gibberellin in the petals, and a higher $\mathrm{ABA} / \mathrm{GA}_{3}$ may lead to early floret opening. 
Vase life

The vase life of gladiolus flowers differed between the cultivars (Figure 1). 'Veronica' and 'Blue Frost' displayed the greatest longevities ( $\geq 6$ days), followed by 'Red Beauty',
'Lavender', 'Rose Supreme', 'Traderhorn', and 'Gold Field' ( 5 to 6 days). The cultivars with the lowest longevities were 'Jester' and 'Green Star' (4 to 5 days), and lastly 'Amsterdam' $(<4)$, which had the lowest vase life compared with the others.

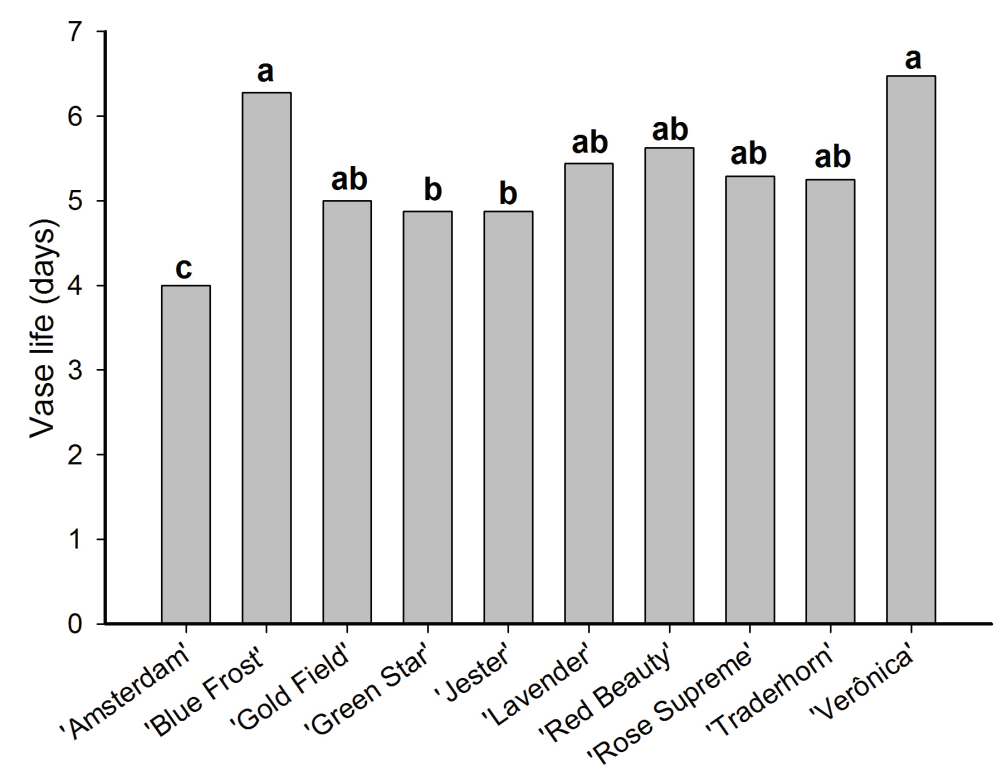

Figure 1. Vase life of 'Amsterdam', 'Blue Frost', 'Gold Field', 'Green Star', 'Jester', 'Lavender', 'Red Beauty', 'Rose Supreme', Traderhorn', and 'Veronica' subjected to the ethylene concentration of $1,000 \mu \mathrm{L} \mathrm{L}{ }^{-1}$. Bars represent mean values. Different letters indicate significant differences by Tukey’s test $(p \leq 0.01)$.

Results found by Serek et al. (1994) show that the difference in vase life between gladiolus cultivars does not have a consistent pattern as regards ethylene and $\mathrm{CO}_{2}$ production; in other words, the ethylene production patterns and respiration of 'Fond Memory', which showed the shortest vase life (3.3 days), and 'Captain Brusch', which showed the longest vase life (5.2 days), were similar in their experiment. Woltering and Van Doorn (1988) concluded, based on the effects of exposure for $24 \mathrm{~h}$ to a concentration of $3 \mu \mathrm{L} \mathrm{L}^{-1}$, that gladiolus was slightly sensitive to ethylene, as they found a small acceleration of senescence in the petal and dehydration of the flower bud.

Hassan et al. (2014) found the greatest vase life in treatments with 1-MCP or STS. On the other hand, Serek et al. (1994), in an experiment with gladiolus flowers, reported that the use of STS as an ethylene inhibitor increased floret opening, but not the durability of florets individually. Thus, the literature has a big divergence in terms of the action of ethylene in gladiolus flowers and the factor determining the difference in vase life between cultivars.

\section{Experiment II}

Total soluble sugars content

There was a difference in total soluble sugars between cultivars in the different flower opening stages (Figure 2). In the three cultivars studied, the soluble sugars content increased up to stage III. In stages IV and V, this content decreased in all variables studied. However, the peak of total soluble sugars content was higher in 'Veronica' (23.5 $\left.\pm 0.44 \mathrm{mg} \mathrm{g}^{-1} \mathrm{FW}\right)$, followed by 'Red Beauty' $(22.6 \pm 0.41$ $\left.\mathrm{mg} \mathrm{g}^{-1} \mathrm{FW}\right)$ and lastly by 'Amsterdam' $\left(21.4 \pm 0.43 \mathrm{mg} \mathrm{g}^{-1}\right.$ FW). 


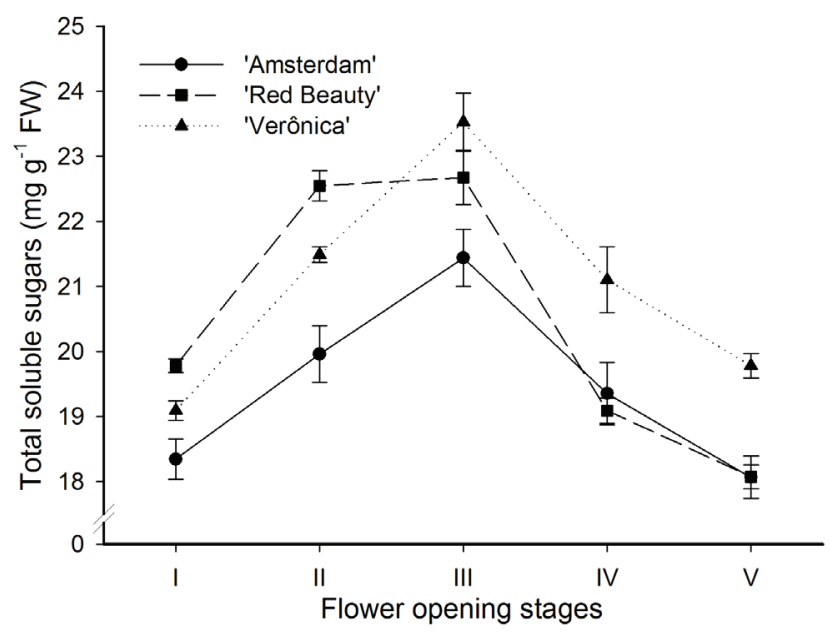

Figure 2. Total soluble sugars content in 'Amsterdam', 'Red Beauty', and 'Veronica' flowers in the five stages of flower opening. Values are means $\pm \operatorname{SE}(n=5)$.

This behavior is similar to that found in Dendrobium crumenatum by Yap et al. (2008), who observed, during the development of flower buds, a gradual increase in total soluble sugars, which reached maximum level after total flower opening, followed by a decrease of approximately $50 \%$ during senescence. In a study conducted by Nabigol et al. (2010) with roses, the authors concluded the glucose, fructose, and sucrose concentrations in the petals of some cultivars with greater vase life were much higher than in others, of lower vase life. Results suggest that the longer vase life of some cultivars may be attributed to the higher concentration of soluble carbohydrates in petals (NABIGOL et al., 2010; NABIGOL et al., 2014).

\section{Reducing sugars content}

As shown in Figure 3, differences were detected in the reducing sugars content between the cultivars in the different flower opening stages. In 'Amsterdam', the peak of reducing carbohydrates content was at flower opening stage III, while that 'Red Beauty' and 'Veronica' showed the peak in stage IV, with $21.4 \pm 0.32$ and $22.3 \pm 0.44 \mathrm{mg}$ $\mathrm{g}^{-1} \mathrm{FW}$, respectively. Further, 'Amsterdam' showed the lowest reducing carbohydrates content $(18.0 \pm 0.48 \mathrm{mg}$ $\mathrm{g}^{-1} \mathrm{FW}$ ) at stage $\mathrm{V}$, while 'Veronica' showed the highest content at this stage $\left(19.3 \pm 0.21 \mathrm{mg} \mathrm{g}^{-1} \mathrm{FW}\right)$.

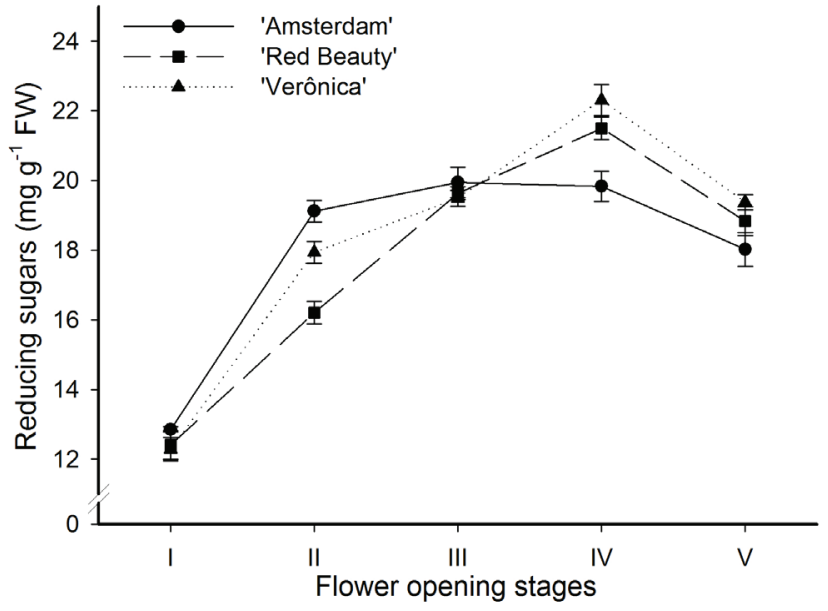

Figure 3. Reducing sugars content in 'Amsterdam', 'Red Beauty', and 'Veronica' in the five stages of flower opening. Values are means $\pm \operatorname{SE}(n=5)$.

In a study conducted by Dar et al. (2014) with Dianthus chinensis, the authors found an increase in reducing sugars content at flower opening with a subsequent decrease in the senescence stage. According to Waithaka et al. (2001), during the opening of gladiolus flowers, reducing sugars, mainly fructose, are redirected to the upper buds at the stalks. Thus, it is believed that this redirection may be the main trigger of senescence in basal flowers. 


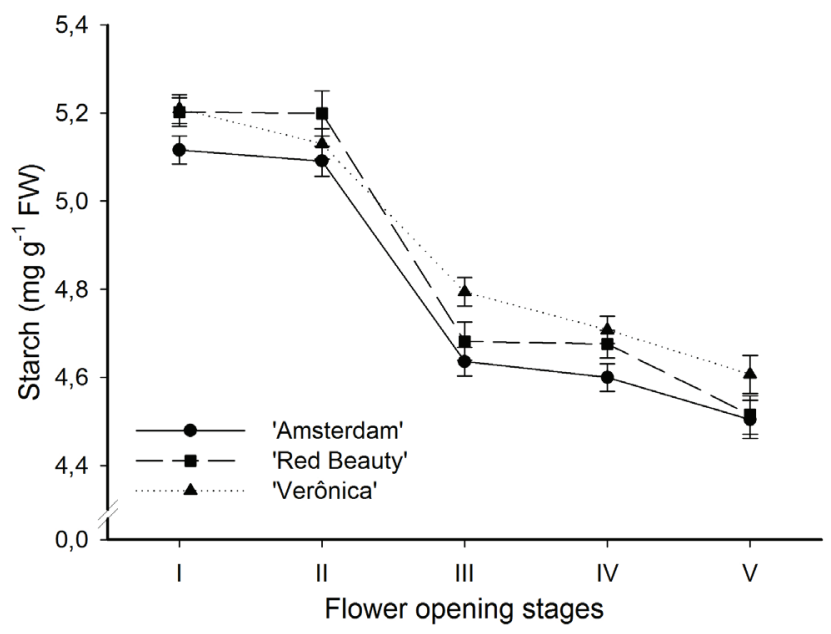

Figure 4. Starch content in 'Amsterdam', 'Red Beauty', and 'Veronica' in the five stages of flower opening. Values are means $\pm \mathrm{SE}(\mathrm{n}=5)$.

\section{Starch content}

In the three cultivars studied, there was a reduction of starch content as the flower opening stages progressed (Figure 4). It was also found that 'Amsterdam' displayed the lowest starch content during the five flower development stages, whereas 'Red Beauty' and 'Veronica' showed similar contents, not differing in stage IV.

Yamane et al. (1991) showed that the predominating sugars in gladiolus flowers were fructose and glucose, and considered that starch in florets was the main source of soluble carbohydrates that contributed in the initial flower expansion stages.

Nabigol et al. (2014) found a difference in starch contents in two rose cultivars: 'Audio' ( $3.2 \mathrm{mg} \mathrm{g}^{-1} \mathrm{FW}$ ) and 'Black Magic' (5.7 $\left.\mathrm{mg} \mathrm{g}^{-1} \mathrm{FW}\right)$; however, total starch concentrations were much lower than the total soluble carbohydrates in both cultivars.

In the current study, the starch content ranged from 5.2 \pm 0.03 to $46 \pm 0.04 \mathrm{mg} \mathrm{g}^{-1} \mathrm{FW}$, whereas the total soluble sugars content ranged from $19.0 \pm 0.15$ to $23.5 \pm 0.44 \mathrm{mg}$ $\mathrm{g}^{-1} \mathrm{FW}$, in 'Veronica'. Therefore, the starch content of the flower buds likely seems not to be the responsible factor for the difference in vase life between cultivars.

\section{CONCLUSIONS}

Ethylene does not influence the flower opening or vase life of the gladiolus cultivars studied. In these cultivars, the maintenance of flower opening is attributed to total soluble sugars content, which, in turn, is a major determinant of the vase life. Thus, once the sensitivity to ethylene and the content of soluble sugars varies among cultivars, other cultivars should be studied to better understand the natural difference in vase life of gladiolus flowers.

\section{ACKNOWLEDGMENTS}

The authors are grateful to Fundação de Amparo à Pesquisa do Estado de Minas Gerais (FAPEMIG) and Conselho Nacional de Desenvolvimento Científico e Tecnológico (CNPq) for financial support.

\section{REFERENCES}

ARORA, A.; WATANABE, S.M.A., B.; TAKADA, K.; EZURA, H. Anovel ethylene receptor homolog gene isolated from ethylene-insensitive flowers of gladiolus (Gladiolus grandiflora Hort.). Biochemical and Biophysical Research Communications, v.351, p.739-744, 2006. DOI: http://dx.doi.org/10.1016/j.bbrc.2006.10.111

CORDEIRO, D.C.; FINGER, F.L; SANTOS, J.S.; KARSTEN, J; BARBOSA, J.G. Sensibilidade da rosa 'Osiana' ao etileno. Bragantia, v.70, n.3, p. 677-681, 2011. DOI: http://dx.doi.org/10.1590/S0006-87052011000300025

DAR, R.A.; TAHIR, I.; AHMAD, S.S. Physiological and biochemical changes associated with flower development and senescence in Dianthus chinensis L. Indian Journal of Plant Physiology, v.19, n.3, p.215-221, 2014. DOI: http://dx.doi.org/10.1007/s40502-014-0104-9

DUBOIS, M.; GILLES, K.A.; HAMILTON, J.K.; REBERS, P.A.; SMITH, F. Colorimetric Method for determination of sugars and related compounds. Analytical Chemistry, v.28, n.3, p.350-356, 1956. DOI: http://dx.doi.org/10.1021/ac60111a017

ELHINDI, K.M. Effects of postharvest pretreatments and preservative solutions on vase life longevity of sweet pea (Lathyrus odoratus L.). Photosynthetica, v.50, n.3, p.371-379, 2012. DOI: http://dx.doi.org/10.1007/s11099-012-0053-3 
HASSAN, F.A.S.; ALI, E. Physiological response of gladiolus flowers to anti-ethylene treatments and their relation to senescence. International Journal of Advanced Research, v.2, n.10, p.188-199, 2014.

KUMAR, M.; SINGH, V. P.; ARORA, A.; SINGH, N. The role of abscisic acid (ABA) in ethylene insensitive Gladiolus (Gladiolus grandiflora Hort.) flower senescence. Acta Plant Physiology, v.36, p.151-159, 2014. DOI: http://dx.doi.org/10.1007/s11738-013-1395-6.

McCREADY, R.M.; GUGGOLZ, J.; SILVIERA, V.; OWENS, H.S. Determination of starch and amylose in vegetables. Application to peas. Analytical Chemistry, v.22, p.1156- 1158, 1950. DOI: http://dx.doi.org/10.1021/ ac60045a016

NABIGOL, A.; NADERI, R.; MOSTOFI, Y. Variation in vase life of cut rose cultivars and soluble carbohydrates content. Acta Horticulturae, v.858, p.199-204, 2010.

NABIGOL, A.; PIRI, S.; NAZARI, A. Changes in soluble carbohydrates content and ethylene production during postharvest period of cut rose flowers. Journal of Applied Science and Agriculture, v.9, n.6, p.2412-2418, 2014.

NELSON, N. A photometric adaptation of the Somogyi method for the determination of glucose. Journal of Biological Chemistry, v.153, p.375-380, 1944.

SCARIOT, V.; PARADISO, R.; ROGERS, H.; DE PASCALE, S., Ethylene control in cut flowers: classical and innovative approaches. Postharvest Biology and Technology, v.97, p. 83-92, 2014. DOI: http://doi. org/10.1016/j.postharvbio.2014.06.010

SEREK, M.; JONES, R.B.; REID, M.S. Role of ethylene in opening and senescence of Gladiolus sp. Flowers. American Society for Horticultural Science, v.119, p.1014-1019, 1994.

SEREK, M.; WOLTERING, E.J.; SISLER, E.C.; FRELLO, S.; SRISKANDARAJAH, S. Controlling ethylene responses in flowers at the receptor level. Biotechnology Advances, v.24, p.368-381, 2006. DOI: http://doi. org/10.1016/j.biotechadv.2006.01.007

SOMOGYI, M. A new reagent for the determination of sugars. Journal of Biological Chemistry, v.160, p.61-68, 1945.

VAN DER MEULEN-MUISERS, J.J.M.; VAN OEVEREN, J.C.; VAN DER PLAS, L.H.W.; VAN TUYL, J.M. Postharvest flower development in asiatic hybrid lilies as related to tepal carbohydrates status. Postharvest Biology and Technology, v. 21, p. 201-211, 2001. DOI: http://doi. org/10.1016/S0925-5214(00)00148-4
VAN DOORN, W.G. Categories of petal senescence and abscission: a re-evaluation. Annals of Botany, v. 87, p. 447456, 2001. DOI: http://doi.org/10.1006/anbo.2000.1357

VAN DOORN, W.G.; HAN, S.S. Postharvest quality of cut lily flowers. Postharvest Biology and Technology, v.62, n.1, p. 1-6, 2011. DOI: http://doi.org/10.1016/j. postharvbio. 2011.04 .013

VEILING HOLAMABRA - FLORES E PLANTAS ORNAMENTAIS. Gladíolo. Critério de Classificação de Produtos. 2009. Available from: $<$ http://www.veiling.com. br/uploads/padrao_qualidade/criterios/gladiolo-fc.pdf $>$. Accessed: Aug. 02, 2016.

WAITHAKA, K.; DODGE, L.L.; REID, M.S. Carbohydrate traffic during opening of gladiolus florets. Journal of Horticultural Science and Biotechnology, v.76, n.1, p.120-124, 2001.

WOLTERING, E.J.; VAN DOORN, W.G. Role of ethylene in senescence of petals morphological and taxonomical relationships. Journal of Experimental Botany, v.39, n.11, p.1605-1616, 1988. DOI: http://doi.org/10.1093/ $\mathrm{jxb} / 39.11 .1605$

YAMADA, T.; TAKATSU, Y.; MANABE, T.; KASUMI, M.; MARUBASHI, W. Suppressive effect of trehalose on apoptotic cell death leading to petal senescence in ethylene-insensitive flowers of gladiolus. Plant Science, v.164, n.2, p. 13-221, 2003. DOI: http://doi.org/10.1016/ S0168-9452(02)00403-X

YAMANE, K.; KAWABATA, S.; SAKIYAMA, R. Changes in water relations, carbohydrate contents and acid invertase activity associated with perianth elongation during anthesis of cut gladiolus flowers. Journal of the Japanese Society for Horticultural Science, v.60, n.2, p.421-428, 1991. DOI: http://doi.org/10.2503/jjshs.60.421

YAMANE, K.; KAWAUCHI, T.; YAMAKI, Y.; FUJISHIGE, N. Effects of treatment with trehalose and sucrose on sugar contents, ion leakage and senescence of florets in cut gladiolus spikes. Acta Horticulturae, v.669, p.351-357, 2005.

YAP, Y.M.; LOH, C.S.; ONG, B.L. Regulation of flower development in Dendrobium crumenatum by changes in carbohydrate contents, water status and cell wall metabolism. Scientiae Horticulturae, v.119, p.59-66, 2008. DOI: http://dx.doi.org/10.1016/j.scienta.2008.06.029 